\title{
Media Framing Analysis and Islamic Minority Sect
}

\author{
Dwi Putri Robiatul Adawiyah' ${ }^{1}$, Fifi Listia Sari ${ }^{1 *}$, Agoes Moh. Moefad ${ }^{1}$ \\ ${ }^{1}$ Universitas Islam Negeri Sunan Ampel, \\ Surabaya, Indonesia
}

Article Information

Submitted April 30, 2021

Revised June 25, 2021

Accepted July 12, 2021

Published October 01, 2021

\begin{abstract}
The process of forming the construction in the media is called framing. Shia framing in the Indonesian mass media is constructed in such a way because it is a minority group that is considered deviant. In this study, the author will explain how the online media BBC News Indonesia and Radar Bangsa frame the Islamic minority sect to their readers and the alignments of the two media in constructing the reality of the Islamic minority sect. This study uses a descriptive qualitative method using the analytical framework of Zhongdang and Kosicki by looking at the syntactic structure, script structure, thematic structure, and rhetorical structure. The results showed that BBC News and Radar Bangsa have different framing in presenting and presenting a fact. The difference in locality makes BBC News Indonesia have a wider perspective in delivering news about minority sects, but Radar Bangsa only discusses the small scope of the report.
\end{abstract}

Keywords: Framing analysis, media framing, Agenda-setting, Islamic minority Sect

\section{Introduction}

Minorities relate to small groups in an area. Minority status is given to a small group of people with striking differences. These differences can be racial, ethnic, cultural, linguistic, and religious identities (Nasution, 2013). Minorities have difficulty being accepted by the majority group and even by the government in which they live. The development of Islamic schools in Indonesia always shows dynamics that never stop (Hakim, 2011). The majority of the Muslim population in Indonesia adheres to the Ahlussunahwaljamaah ideology. However, historians' opinions that the Shia minority played a role in developing the sect in the archipelago (Ramli, 2017). The issue of minority sects in Islam is an issue that tends to attract media attention. Media owners generally think that news about minority sects in Islam is a source of news that can attract people's attention.

In the era of technology, not a second is missed in the mass media. Every occurrence can be easily accessed with just the palm of your hand. The media that is in great demand today is online mass media. This online mass media is very easy and fast in accessing information. The speed of online mass media access causes the public to know about the latest news circulating (Ridwan, 2017).

\footnotetext{
*Author Correspondence: Fifi Listia Sari, Email: fifilistiasari@gmail.com, UIN Sunan Ampel, Jl. Ahmad Yani No.117, Jemur Wonosari, Kec. Wonocolo, Kota Surabaya, Jawa Timur 60237
}

Copyright (C) 2021 Dwi Putri Robiatul Adawiyah, Fifi Listia Sari, Agoes Moh. Moefad 
One of online mass media functions is to convey information from communicators to communicants or the general public. Apart from being a medium of data, the function of broadcasting media (broadcasting media), press media, and communication media are to connect one to another, from one place or agency to another (Lahyanto, 2018).

It is not just news delivery in delivering messages to the general public. Still, there is a sharing of ideas, thoughts, facts, or opinions from the communicator to the communicant. The delivery of this message aims to change and shape the behavior of the communicant. According to Hierbert Uguran and Bohn, as quoted in Romli, mass communication has different components from other types of communication. These components include media, regulation, filter, audience, and reciprocity. These components vary from the elements in general communication (Romli, 2016).

Online mass media has an important role in conveying information to the public. Online Mass Media can reach all levels of society, from rural to urban communities. The level of public trust in the mass media is one indicator of the mass media's existence in society. In addition, separately online mass media has different ideologies in presenting information (Mahyuddin, 2019). For example, Republika online has a national religious ideology (Zuhra, 2012). Various interesting occurrences, including minority religious sects, get the great attention of journalists (Minardi, 2019).

The mass media have different perspectives in writing, determining news sources, and defining actors and events (Ayu and Pratiwi, 2019). Framing is part of the construction process, and social reality is interpreted and constructed with a certain meaning which is finally shown in the news (Pinontoan, 2020). The media carry out agenda-setting by choosing interesting issues and finally paying attention to those issues (McQuail, 2011). With the characteristics of online mass media, news spread to the public is quickly accepted. The spread of information will sometimes vary from one media to another. This difference is because there is a process of social media construction that does not escape the partiality of the mass media to the media owners or capitalists. The facts here are the result of construction. In this case, the news is not the real reality but is the result of the structure of reality. So it is the media and journalists who actively shape reality (Eriyanto, 2002). The social construction of mass media does not escape the mass media's partiality to the press. Communicators are involved in making news, technically, economically, and ideologically. The media are always engaged in presenting the reality arranged not to reflect the real truth (Rinawati, 2006).

The process of forming this construction is called framing. In the framing perspective, a selection process highlights certain aspects of reality carried out by the media. In addition, there is a placement of information in a specific context so that certain issues get a bigger allocation than other issues. The emphasis is on how the text is presented and defined to determine journalists' perspectives when selecting issues and writing news (Eriyanto, 2002). The information about the process of allegiance of followers of the Shi'a sect to Sunnis in Sampang attracted the interest of online mass media in Indonesia.

Numerous types of research on framing analysis on minority issues in Islam have been 
carried out; first, Osama Kanaker, Mohamed Oklah Abughazlih, and Mohd Faizal Kasmani entitled "Media Framing of Minorities' Crisis: A Study on Al Jazeera and BBC News Coverage of the Rohingya." In contrast to the research conducted by researchers regarding the process of taking allegiance from Shia followers to Sunnis, this research examines cases in the Rohingya describes the causes and consequences of the Rohingya cases. The study found six main causes of the Rohingya crisis. The $\mathrm{BBC}$ and Aljazeera agree that the main cause is military security, as much as $91.8 \%$, while the remaining $8.2 \%$ are other reasons. As for the consequences, Al Jazeera independently disclosed 17 consequences and the BBC 10 consequences. The three main consequences in the Rohingya case are deportation, massacres, and repression. The whole frame adopted by Al Jazeera and the $\mathrm{BBC}$ is largely powerless and marginally a responsive framework.

The second research was conducted by Dwi Putri Robiatul Adawiyah and Agoes Moh. Moefad entitled "Construction of Reality and Framing Analysis of Reporting on MuslimHindu Riots in India on CNN.Com Online Media." Based on the results of research and discussion conducted as part of Robert N. Entman's framing analysis by defining the problem, diagnosing the cause (estimating the problem or source of the problem), making moral judgments (making moral decisions), and recommending treatment (highlighting solutions). CNN's online media framing coverage of the Muslim-Hindu riots is filled with various supports and alternative solutions to US President Donald Trump. On the other hand, there are stereotypes or labels such as extremism and terrorism aimed at Muslims (Adawiyah \& Moefad, 2020).
The next research is entitled "Analysis of Framing About Terrorism Discourse in Mass Media (Sabili Magazine)" by Ummy Hanifah. Based on the results of research and discussion conducted from the perspective of the overall framework, it is concluded that Sabili supports radical Islamic groups. The study's results can be inferred from all the sources interviewed by Sabilli, who comes from radical Islamic circles. Apart from radical Islam, Sabili tends to give a small portion to references from different groups. This tendency is related to the ideology adopted by Sabili magazine as a propaganda medium that has an Islamic ideology (Hanifah, 2019).

Ade Riana Farida also conducted a similar study titled "Liberal Islam in the Media Frame: Framing Analysis of Gatra and Sabili Magazines." The results of research and discussion of text analysis show that the magazine "Gatra" tends to accommodate the ideas brought by liberal Islamic thought actively. This tendency is seen in the reporting framework, for example, "Free Islam is in competition for consolidation and the strength of militant Islam." For Sabili magazine, independent Islam tends to be considered a dangerous idea because it can deny faith, threaten the purity of Islam, is not original, and is seen as a continuation of the renewal of secular thought contained in the diagram, as stated in the news "Free Islam has no clear basis" ( Farida, 2011).

One of the conflicts of religious minorities is currently being resolved and is now a concern in the case of Shia and Sunni in the Sampang Regency. Currently, the issue has reached a new phase. After eight years of Shia followers being in refugee camps, on November 5, 2020, the Shia leadership and 274 other people were willing to be pledged 
to become followers of the Sunni sect, while 21 others continued to stick with their sect (Lumbanrau, 2020). There are many versions regarding the cause of this betrayal. Some said people visited them a month before the abdication because the government forced them. Some others say there is no coercion from any party but purely from their will. Meanwhile, the other party stated that they did not know anything about allegiance, only following the leader of the Shi'a sect. Another source indicated that they were tired of looking for a way out, so the way he chose was to leave his faith.

The existence of various points of view on an issue cannot be separated from the role of the media in conveying information to the public. Online mass media is one media shaping public perception to find out occurrences that the public cannot directly reach. How the media frames the conversion of Shi'a followers to Sunnis can influence people's thoughts and perceptions. It is important to know whether the media in Indonesia is neutral or impartial. If a media still has an element of partisanship, the government's role is needed to strive for media neutrality to be realized (Farida, 2011).

In this research, the author chose BBC News Indonesia and Radar Bangsa. British Broadcasting Company (BBC) News Indonesia is one of the expansions of $\mathrm{BBC}$ News International based in London, England. The reason for choosing BBC News Indonesia is because it has extensive and detailed information about the Shia massacre case. In addition, the BBC is also believed to be accurate, independent, and oriented to the public interest, which makes it a reference for people around the world. Research on the world's general trust in the media shows that most of the world's people, as much as
$48 \%$ believe in the $\mathrm{BBC}$ as a reference for information (BBC News, 2006).

Meanwhile, Radar Bangsa is a media owned by PT Media Radar Bangsa, which branches in various Indonesian regions. The selection of the Radar Bangsa media was due to the intensity of the media in reporting on the process of converting Shia followers to Sunnis, and most of the news focused on the response from the government and mass organizations Sampang.

Based on the background above, the research aims to analyze the differences between BBC News Indonesia online mass media and Radar Bangsa in framing the news of the conversion of Shia followers to Sunnis in Sampang by using the Zhongdang and Kosicki model framing analysis.

In the framing analysis, Zhandang and Kosicki's model uses a syntactic structure, script structure, thematic structure, and rhetorical structure:

1. The syntactic structure is the structure observed in the news chart. Syntax relates to how journalists organize news such as statements, opinions, quotes, observations, and events. The most popular syntactic forms are titles, episodes, settings, and endings.

2. The script structure is to see how journalists package a news story. The general form of script structure is $5 \mathrm{~W}+1 \mathrm{H}$, Who, What, When, Where, Why, and How.

3. The thematic structure is the journalist's perspective on an event in a proposition, sentence, or relationship between sentences that make up the text as a whole.

4. The rhetorical structure is the journalist's way of emphasizing certain meanings reflected in the choice of style and words. 
In addition, the word emphasis can be accomplished through graphics in pictures, photos, tables, and others (Nurhasanah, 2021).

\section{Method}

This study aims to examine how the BBC News Indonesia online media and Radar Bangsa online media frame the Islamic minority sect to their readers and the alignments of the two media in constructing the reality of the Islamic minority sect. This study uses a framing analysis of the Zhongdang and Kosicki model, which has four dimensions: syntactic structure, script structure, thematic structure, and rhetorical structure (Sobur, 2015).

This type of research is descriptive research because the data studied are words in the news and not numeric data. The paradigm used is constructionism. The analysis with a constructionism paradigm will answer an issue and determine how the event or reality is constructed and how the construction is formed. This construction paradigm is often called the production or meaning exchange paradigm (Eriyanto, 2002).

As an analytical tool, the researcher uses the Zhongdang and Kosicki model of framing analysis to examine the framing of the text content.

The object of this research is the text of three Shi'a sect news in the BBC News Indonesia online mass media, taken from 03-05 November 2020, and five Shi'a sect news from the Radar Bangsa, taken from 02-06 November 2020. Researchers chose publications in November 2020 because of November 2020. The topic of news coverage is more dominated by the news of the betrayal of the Shi'a sect to the Ahlussunnahwaljamaah teachings in Sampang.

In this study, the focus of the news was:

1. Differences in the perception of the regent and former leaders of ex. Shi'ism regarding the meaning of allegiance.

2. The return of Shiites to Sunni teachings as a form of despair.

3. The government is accused of defeating the minority in the majority's interests.

4. Some conditions are carried out before the pledge.

\section{Result and Discussion}

Disparities cause differences in point of view in the ideological basis of the mass media. This ideological difference is marked by several arguments from different sources and references. The return of the Shi'a sect followers to the Ahlussunnah thought in the BBC and Radar Bangsa online media has a different point of view. There are mixed interviews from sources with different portions on the BBC online media. The majority of the interviews were with the Regent and the Madura religious leader Alliance and Tajul Muluk as the coordinator of the Sampang refugees. Meanwhile, refugee residents, PCNU, Rois Syariah, and peace activists received a smaller portion.

The emergence of fear of taqqiyah has been accomplished as before. Several issues received attention from the BBC's online media, among others: first, highlighting the distrust of citizens towards ustadz Tajul Muluk, who returned to the teachings of Ahlussunnah-second, highlighting the differences in perceptions between the regent of Sampang Regency and the coordinator of the refugees, Tajul Muluk, regarding the 
purpose of taking allegiance and returning from refugee camps. Tajul Muluk and the refugee residents expressed their desire to return home, while the regent of Sampang Regency stated the opposite statement. Third, there are differences in perceptions regarding the return of refugees who have taken allegiance; the community offers it to the religious leader while the religious leader offers it to the community. The regent leaves it to the religious leader and the community. Furthermore, the BBC Indonesia also presented the opinion of peace activists who stated that the conflict resolution carried out could create a bad precedent because it defeated minority opinions for the majority's interests.

Slightly different from the Radar Bangsa online media, most of the interviews were with Tajul Muluk, the regent and the head of the Ansor Branch Manager. Meanwhile, the Secretary of Sampang Regency, the chairman of the PCNU, the refugees, and the chairman of the council of the Sampang Elected Region received a smaller portion. Several issues that have attracted the attention of the Radar Bangsa online media are: first, highlighting the willingness to take allegiance. Tajul Muluk conveyed that there was no coercion in taking allegiance. The desire to return home persists but is not a priority and is offered to the Central, Provincial, and Regency Governments and agrees to all the requirements given by the religious leader. Second, highlighting the views of the Head of the Ansor Branch Manager who asked the community to obey/taqdim to the religious leader, so if the religious leader in Madura, especially in Sampang, want to accept it, it is also necessary to obey the same attitude from the people below. Third, the acceptance from PCNU Sampang of the pledge made by the refugees. In addition, they want to detect the seriousness of the refugees. If they have returned, the people themselves will pick them up. Moreover, finally, the opinion of one of the refugees, although it did not get a large portion, was quite interesting. One of the residents conveyed his ignorance about the pledge because he did obedience/ taqdim to Tajul as a respected cleric.

\section{BBC.com}

\section{Analysis of News 1}

Title: " Allegiance of Sampang Shia refugees to become Sunnis: Find a way to go home, but the trauma of the residents 'scars' and will never recover' and also worries about 'taqiyyah'"

\section{Syntactic Structure}

In the syntactic structure used for writing news headlines, there are inconsistencies in using capital letters at the beginning of words. In terms of content, it has clearly explained the reasons for betrayal as a way to return home. The selected resource persons consisted of responses from the residents of Karang Gayam Village - one of the Shi'a refugees -the Head of PCNU Sampang Branch, Kyai Itqon, Madura's religious leader, Tajul Muluk, and the Regent of Sampang, Slamet Junaidi.

However, on the other hand, BBC.com also shows some differences of opinion among the sources. The first is the difference of opinion between the Madurese clerics and the residents of Karang Gayam Village. The Madurese scholars believe that the return of the Shia followers depends on the community's decision, while the natives of Karang Gayam village state that the return depends entirely on the religious leader/ kyai. The second is the difference of opinion 
between the Shia leader Tajul Muluk and the Regent of Sampang. The Shia leader Tajul Muluk stated an allegiance to return home, but Regent Slamet Junaidi declared it pure allegiance without any desire to go home. Differences in the informants' perceptions, both between the Madurese ulema and the original residents of Karang Gayam village and between the Shia Leaders and the Sampang Regent, can trigger confusion from readers regarding the validity of the information.

\section{Script Structure}

The structure of the existing script is complete, initiating from the underlying reason for taking allegiance, why it can happen, and how the community responds to the existence of allegiance.

\section{Thematic Structure}

Thematically, this news invites the readers to look at the problem of infidelity from various sources' perspectives in a complex and comprehensive manner.

\section{Rhetorical Structure}

The image displayed in the BBC.com news support the information conveyed. The image shows an image of the arson that took place nine years ago to show the expression of concern from Madurese clerics about the bloodshed.

\section{Analysis of News 2}

Title: "Shia Refugee of Sampang, Madura: Between the choice of faith and hope to return"

\section{Syntactic Structure}

The syntactic structure shows the shortcomings of bbc.com, which is the lack of consistency in writing capital letters at the beginning of words. The contents of the news show one informant interviewed, specifically the Shia leader, Tajul Muluk. The news content also shows that some refugees want to go home but stick to their Shia beliefs, but the news author does not present interviews with the relevant sources.

\section{Script Structure}

Overall the news is incomplete-the how and why elements have not been revealed. News authors should reveal how and why the Shia refugees in Sampang are significantly difficult to choose faith or go home. The how and why elements are important to reveal. The content of this news gives the impression of a defect in news writing by journalists.

\section{Thematic Structure}

Thematically, this news invites the readers to notice the events experienced by Tajul and 300 other Shia followers who are ready to Return to Sunnism. In the next line, there is a statement that although some followers also want to go home, they still believe in following the Shia sect.

\section{Rhetorical Structure}

The photos displayed on BBC.com news shows photos of peaceful worship carried out by the Shia sect nine years ago. These images support the news information.

\section{Analysis of News 3}

Title: "Hundreds of Shia refugees in Sampang were sworn in as Sunnis in the midst of wanting to return home: The government is accused of defeating the minority for the sake of the majority'"

\section{Syntactic Structure}

The selection of sources in this news is relatively diverse, including the Shiite leader, Tajul Muluk, Sampang Regent, peace activists from The Asian Muslim Action Network (AMAN) Indonesia, Siti Hanifah, Nahdlatul 
Ulama Sampang Branch Manager, Syafiudin Abdul Wahid, Main Secretary of DPW ABI East Java, Muhammad Muadz. In terms of writing the title, there are still inconsistencies in capital letters at the beginning of the word. The title is also quite brave because it directs the government as the authorized party.

On the other hand, this news also reveals controversial statements from sources who are not willing to take allegiance to Sunnis. The existence of a controversial sentence in this news impacts the reader's thinking about the current case.

\section{Script Structure}

The structure of the news script appears to present a fairly complete description of the desire to return home and accusations that the government is considered bad in handling this case of betrayal. This news also presents various points of view to see the widespread problem that occurs so that readers can understand how the government deals with the allegiance process.

\section{Thematic Structure}

Thematically, this news invites readers to look at the issue of more than 270 Shia refugees from Madura who underwent an allegiance to become Sunni in Sampang. The process of taking the allegiance or Sunni pledge was witnessed by dozens of clerics and community leaders from Sampang.

\section{Rhetorical Structure}

The photos displayed in the BBC.com news support the information conveyed. The first image depicts Tajul Muluk, who enters the Trunojoyo Sampang hall to pledge allegiance to Sunni. The second image depicts refugees entering the Trunojoyo Sampang hall to undergo allegiance to Sunnis. The third image depicts the Shia sect praying. The fourth image depicts hundreds of refugees carrying out the return to Suni pledge at Trunojoyo hall. The sixth image is a flashback of the incident nine years ago when the masses burned down the house of the Shia followers of Sampang. The seventh image depicts the Sampang refugee mothers accompanying their children to play in the front yard of the Puspa Agro flat. The eighth image is a photo of the regent of Sampang, Slamet Junaidi, who is being interviewed regarding the communication between Tajul Muluk and the Sampang scholars. The ninth photo depicts Tajul Muluk and his followers worshipping on the fourth floor of Puspa Agro flat. In addition to the nine images, other images also support the information presented.

\section{Radar Bangsa}

\section{Analysis of News 1}

Title: "This is the confession of the Shia leadership in Sampang, who will pledge to return to Sunnis"

\section{Syntactic Structure}

There is an inconsistent error in capital letters in the title in the syntactic structure used for news headlines. There are also typos in "ALLOH SWT" and "Pengucapan". In terms of content, the emphasis is more on reporting about Shia followers after returning to Sunni thought. The informant chosen was only Ustadz Tajul Muluk, who had a role in returning to Sunni thought even though he was involved with several people, but these other people were not used as sources.

On the other hand, Radar Bangsa also shows that there are things that have been done to make a vow to return to Sunni thought with other followers. Like Ustadz Tajul Muluk, who then asked the Regent of Sampang for 
help to facilitate his wish to return to Sunni with other followers. The news also shows the steps taken before making a joint pledge, specifically severing relations with the Shia community, refusing activities from Shia leaders in refugee camps, refusing to attend invitations from Shia residents, transferring sons and daughters to Islamic boarding schools who are followers of Ahlussunah Wal Jamaah and protecting followers from the doctrine, which leads to Shi'ism, especially towards children. The news made the readers seem convinced of the seriousness of Ustadz Tajul Muluk, who would not turn to the Shia sect forever.

\section{Script Structure}

The structure of the existing script is not complete; there are only reasons underlying the allegiance, why it can happen and suggestions after returning to Sunni thought. The news also does not articulate another issue, such as public responses or other important things.

\section{Thematic Structure}

Thematically, this news invites readers to notice the seriousness of Ustadz Tajul Muluk and other followers to return to Sunni thought.

\section{Rhetorical Structure}

The image displayed on the Radar Bangsa news does not fully support the news contents conveyed. The news shows Ustad Tajul's close up photo without any other supporting elements.

\section{Analysis of News 2}

Title:"TheSampang Regency Government prepares a pavilion for allegiance, Shia people led by Tajul Muluk"

\section{Syntactic Structure}

Radar Bangsa shows the lack of consistency in writing capital letters at the beginning of words or titles from the syntactic structure. Even in the image description in the top layout, there are still typos related to image captions. There is one image that is not given any information. Even it contains many capital letters that should be written in lower case. The contents of the news show one informant interviewed, Yuliadi Setiawan. The news content only displays the description of the title without any other events/opinions to support the news.

\section{Script Structure}

Overall the news displayed is incomplete-the how and why elements have not been revealed. News authors should reveal how and why the hall was prepared and why the reasons were not disclosed in detail. The content of this news gives the impression of a defect in news writing by journalists because it seems that the news does not meet the $5 w+1 h$ news elements.

\section{Thematic Structure}

Thematically, this news invites the readers to see the Shia people led by Tajul Muluk, ready to be sworn in at the Sampang hall.

4. Rhetorical Structure

The display image of Radar Bangsa in the news support the information conveyed. The news featured an image of the pavilion prepared by the Sampang Regency Government for the allegiance process of the Shia led by Tajuk Muluk.

\section{Analysis of News 3}

Title: PC Ansor Sampang Warmly welcomes, Return of the Shia people to 
Aswaja.

\section{Syntactic Structure}

In terms of writing, the title is still the same as the last news, which is still visible inconsistencies in capital letters at the beginning of words. The news conveyed is only narrative from the source. The selection of only one source, specifically the chairman Muhammad Khoiron and Ustadz Tajul Muluk as the main report, was not used as a source.

On the other hand, this news also expresses that the incident that caused the loss of life will not be repeated. Readers who follow the news updates may already know, but new readers will be confused because this news does not explain the chronology of the cases that are happening.

2. Script Structure

Overall the news that is displayed is quite complete. The news content already contains news $5 \mathrm{w}+1 \mathrm{~h}$ elements, but because it only uses a single source, the reader does not know other points of view from different sources. Journalists often use a single source to absorb all the information. This model of sources without comparison causes readers to be led in their opinion according to those conveyed by a single source. News authors should be able to find other sources to reveal other reasons.

\section{Thematic Structure}

Thematically, this news shows that PC Ansor Sampang warmly welcomes the return of Shia residents to the Ahlusunnah thought.

\section{Rhetorical Structure}

The images displayed in the Radar Bangsa news support the information conveyed. The image shows the expression of PC Ansor Sampang in welcoming the Shia people back to the Ahlusunnah.

\section{Analysis of News 4}

Title: Pledge before the religious leader of Madura, Shia leaders in Sampang and their followers return to Aswaja.

\section{Syntactic Structure}

In the syntactic structure used for writing news headlines, there are inconsistencies in using capital letters at the beginning of words in the title. In terms of the content of the news, it has clearly explained the procession of the pledge to be carried out. Even though this news is not free from typos in words "Penerintah", which should be "Pemerintah", "naupun", which should be "maupun". The selected resource persons were from various kinds, ranging from $\mathrm{H}$ Slamet Junaidi as Sampang Regent, Suyati (age 63) male from Blu'uran Village who performed allegiance, Chairman of NU Sampang PC KH Itqon Busiri, residents in conflict areas, and temporary Head of Bakesbangpol Sampang, Anang Djoenaedi.

However, on the other hand, Radar Bangsa also shows some differences of opinion between the informants. There is a statement "just for information on the number of Shia residents from Karang Gayam Village, Omben Sub-district and Nangkernang Village, Karang Penang Sub-district in the Puspa Argo Jemundo Sidoarjo Flats 347 people" but at the bottom of the news, "Temporary Head of Bakesbangpol Sampang Anang Djoenaedi admitted that he was still recapitulating the number and promised will be delivered one door. This statement makes the reader confused by the number of pledged Shiites.

\section{Script Structure}

The structure of the existing script is quite complete, from the reasons for taking the allegiance to how taking the allegiance 
and what to do after the return to Sunni has been described, albeit briefly.

\section{Thematic Structure}

Thematically, this news invites the readers to notice reading the pledge and its objectives.

\section{Rhetorical Structure}

The news featured an image to support information in an image of Ustadz Tajul Muluk al Ali Murtadho. The Shia leader in Sampang and his family pledged to return to the teachings of Ahlussunah Wal Jamaah. Below the picture has also been given a photo caption.

\section{Analysis of News 5}

Title: Need to Resurrect Team 5, After the Pronunciation of the Shia People's Pledge in Sampang

\section{Syntactic Structure}

From a different syntactic structure from the previous news, the format for writing the title is correct in this news. The news content does not match the title because the news provides other information that does not support the news title. Featuring one of several informants interviewed, namely Fadol, Chairman of the Sampang council, PKB party Politician from the Omben-Camplong District,

\section{Script Structure}

Overall the news displayed is incomplete-the how and what elements have not been revealed. News authors should reveal the reasons for how and what to revive Team 5 after the Shia pledge was made in Sampang. This news element includes something important to reveal. The content of this news gives the impression of a defect in news writing by journalists.

\section{Thematic Structure}

Thematically, this news invites the readers to look at the problem of infidelity from various sources' perspectives in a complex and comprehensive manner.

\section{Rhetorical Structure}

The images displayed on the Radar Bangsa news support the information conveyed. The image is shown after the oath of allegiance by Shia residents in Sampang.

\section{Conclusion}

Based on the research and discussion results, it can be concluded that BBC News Indonesia and Radar Bangsa have different localities in viewing the events of the return of the Shi'a adherents to the teachings of Ahlussunnahwaljamaah. The difference in point of view is caused by the ideological basis adopted by the two different media.

The researcher uses the framing analysis of the Zhongdang and Kosicki model, specifically by using a syntactic structure, script structure, thematic structure, and rhetorical structure. In this study explain: First, the frame that became the idea was the difference in the perception of the regent and former ex-Shi'a leaders regarding the meaning of allegiance. Second, the return of Shiites to Sunni teachings as a form of despair. Third, the government is accused of defeating the minority in the majority's interests. Fourth, several conditions were disclosed before taking the pledge of allegiance from Shia to Sunni. 


\section{Bibliography}

Adawiyah, D. P. R., \& Moefad, A. M. (2020). Konstruksi realitas dan framing analysis pemberitaan kerusuhan muslim-hindu di india pada media online cnn.com. ORASI: Jurnal Dakwah Dan Komunikasi, 11(2), 149. https://doi.org/10.24235/ orasi.v11i2.6601

Ayu, D., Pratiwi. (2019). Agenda media dalam pemberitaan Top Up Uang elektronik di media online kompas.com. Widya Komunika, 9(1), 86-104.

BBC News. (2006). Media lebih dipercaya [BBCIndonesia.com]. http://www. bbc.co.uk/indonesian/indepth / story/2006/05/printable/060503_pers. shtml

Eriyanto. (2002). Analisis Framing. Yogyakarta: LKIS.

Farida, A. B. (2011). Islam Liberal dalam Bingkai Media: Analisis Framing Majalah Gatra dan Sabili. Komunika: Jurnal Dakwah dan Komunikasi, 5(1), 44-57. https://doi.org/10.24090/komunika. v5i1.769

Hakim, Lukman dkk. 2011. Mengenal Pemikiran Islam Liberal. Jurnal Substantia. Vol 14 No 1. 179-198.

Hanifah, U. (2019). Analisis Framing Tentang Wacana Terorisme di Media Massa (Majalah Sabili). Komunika: Jurnal Dakwah Dan Komunikasi, 13(2), 283-298. https://doi.org/10.24090/ komunika.v13i2.2053

Lahyanto, N. (2018). Media Massa dan Pasar Modal. Media Center.

Lumbanrau, R. E. (2020). Ratusan pengungsi Syiah Sampang dibaiat menjadi Suni di tengah keinginan pulang kampung:
Pemerintah dituding 'mengalahkan minoritas demi keinginan mayoritas. $B B C$ News Indonesia.

Mahyuddin. (2019). Sosiologi Komunikasi. Makassar : Shofia.

McQuail, D. (2011). Teori Komunikasi Massa. Jakarta: Salemba Humanika.

Minardi, Anton. 2019. Islam sebagai Solusi Terorisme Internasional. Pengajian Melayu: 27-64

Nasution, M Imaduddin. 2013. Demokrasi dan Politik Minoritas di Indonesia. Jurnal Politica. Vol 4 No 2. 313-335.

Nadie, Lahyanto. (2018). Media Massa dan Pasar Modal. Jakarta: Media Center.

Nurhasanah, een. (2021). Analisis Framing Zhongdang Pan dan Gerald M. Kosicki. Jurnal Pebas: Jurnal Pendidikan, Bahasa dan Sastra. Vol 1, No. 1 Agustus 2021., 44-54.

Pinontoan, N. A., \& Wahid, U. (2020). Analisis Framing Pemberitaan Banjir Jakarta Januari 2020. Jurnal Komunikasi Dan Teknologi Informasi, 12(1), 11-24

Ridwan, Muhammad dkk. 2017. Wacana Paham Keagamaan TV One dan Metro TV dalam Pemberitaan Demo 411 di Jakarta. Jurnal Komunika: Jurnal Dakwah dan Komunikasi. Vol 11, No. 2, 167-183.

Rinawati, Rini. 2006. Komunikasi dan Pembangunan Partisipatif. Mediator: Jurnal Komunikasi: 175-184

Romli, K. (2016). Komunikasi Massa. Grasindo. Rusmulyadi \& Imelda Cholidah, Lida (2017). Relasi Mayoritas-Minoritas Dan Radikalisme Dalam Konstruksi Media Islam. Al-Adalah, 20 (1), 52.

Sobur, A. (2015). Analisis Teks Media. Rosdakarya. 
Wahid, Ramli Abdul. 2017. Aliran Minoritas dalam Islam di Indonesia. Journal of Contemporary Islam and Moeslim Societis. Vol 01. No.2. 141-163

Zuhra, Wan Ulfa Nur (2012). Skripsi: "Citra
Homoseksual dalam Media Massa Online Nasional, Analisis Framing Citra Homoseksual dalam Tempo.co dan Republika Online", Medan: Universitas Sumatera Utara, 2012 